\title{
A MOSAIC DISEASE OF THE YAM, DIOSCOREA ROTUNDATA, IN PUERTO RICO
}

A mosaic disease affecting yams, Dioscorea rotundala Poir, was first observed in the Caguana county near the town of Utuado in August 1952. The plantation visited consisted of around 7 acres, all the plants in which were totally affected. It has been observed in other parts of the Island since.

The most important symptoms of the disease in the field consist of yellow

${ }^{1}$ Riollano, A., A new variety of muskmelon for Puerto Rico, Amer. Soc. Hort. Sci. 42 574, 1943.

2 Robbins, S. R., personal communication, 1954.

${ }^{3}$ Adsuar, J., and Cruz Miret, A., Virus diseases of cucumbers in Puerto Rico, Technical Paper No. 6, pp. 3-14, Univ. of Puerto Rico Agricultural Expt. Station, 1950. 

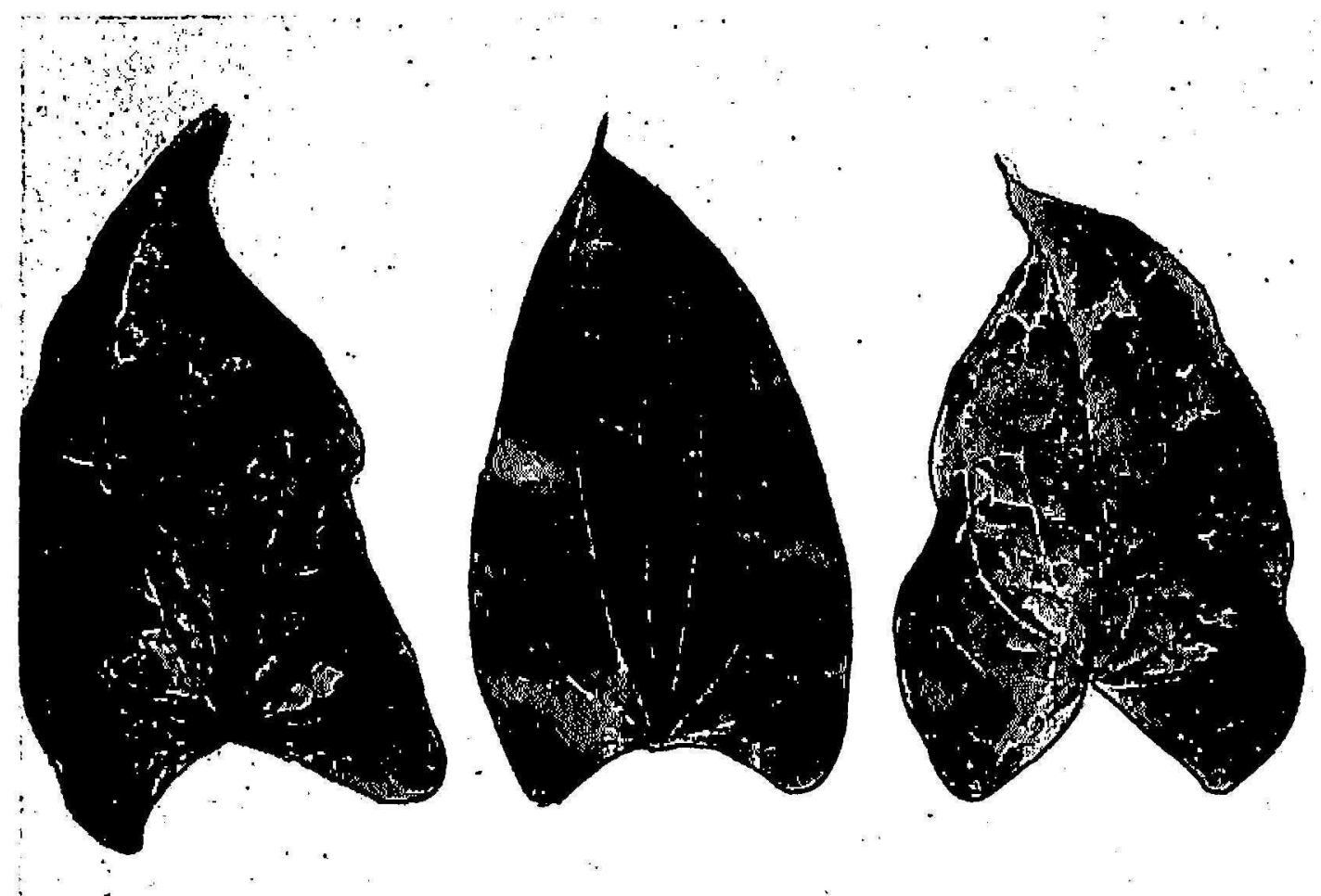

Frg. 1.-Leaves of yams affected with the mosaic with healthy leaf at center.

and dark green patches on the leaves (fig. 1) accompanied by a slight distortion of the leaf lamina. Not all the leaves exhibit the mosaic, however, and in the majority of cases only about half of the leaves are affected, the others presenting the glossy green color characteristic of the healthy plant. Healthy plants are noticeably larger than diseased ones.

The virus is transmissible to yam, tobacco, pepper, and cucumber. It can be transmitted to susceptible plants with considerable difficulty by rubbing the infectious sap with the aid of carborundum and oceasionally by grafting (tuber grafting) in the case of yams. The best method of transmission from yam to yam is by needle pricking through an infected leaf wrapped around a stem or petiole of a healthy. yam. After surcessful establishment on tobacco, the virus is more easily transmissible by sap inoculation to tobac'o and from tobac'o to pepper and cucumber.

The disease is transmitted through the tubers of infected yam plants. Roots from apparently healthy yams are rapuble of producing diseased plants.

The insect vector of the disease is not known.

The virus withstands exposure for 10 minutes at $50^{\circ} \mathrm{C}$., but is inactivated at $60^{\circ} \mathrm{C}$. It retains infectivity at a dilution of $1: 1000$ hut not at $1: 10,000$. Infectivity of the virus in expressed juice is lost before 24 hours at room temperature. When infected leaves are air-dried in the laboratory they retain their infectivity for 10 days but lose it after 24 days. The virus is still infectious after 1 month at $-5^{\circ} \mathrm{C}$. 
Besides the yam, Dioscorea rolundata, the virus infects Cucumis sativus, Nicotiana tabacum, and Capsicum frutescens. We have not been able to determine the susceptibility of other varieties or species of yams to the virus.

$\mathrm{Cook}^{1}$ has reported a mosaic disease of yam (Dioscorea sp.) from Puerto Rico and Deighton ${ }^{2}{ }^{3}$ has described a similar disease from Africa. As far as we have been able to determine those are the only two viruslike diseases occurring in yams so far reported. The disease dealt with in this note is probably similar to, if not identical with the ones observed by Cook and Deighton, but unfortunately comparison is impossible as those investigators did not study the causal viruses concerned.

\section{J. Adsuar}

Department of Plant Palhology 